\section{IMMUNITY CONFERRED BY THE TRANS- FER OF IMMUNE AND OF MIXED IMMUNE AND SENSITIZED SERUMS *}

\author{
HENRY SEWALL, M.D., \\ W. C. MITCHELL, M.D. \\ AND) \\ CUTHBERT POWELL, M.D. \\ DENVER
}

We venture to present a few facts on an intricate subject, conscious that their full meaning and value must await the verdict of prolonged research.

In a recent investigation by two of $\mathrm{us}^{1}$ it was found that when horse serum was dropped into the nose of a guinea-pig on alternate days, as few as four times, the animal became biologically modified in one of two opposite directions. A "toxic" injection of a large dose of serum given by the vein sixteen days after the last instiilation could strongly shock or kill the guinea-pig. That is, the animal had become "sensitized" to the horse serum absorbed through the mucous membrane of the nose as if it had been given by subcutaneous injection. In certain animals, however, the toxic injection of horse serum not only did not kill, but produced scarcely noticeable symptoms of reaction.

Such a result would be attributed to incomplete absorption of the antigen were it not that a second large intravenous injection of serum, given two weeks after the first, was likewise frequently withstood.

In the work referred to it was found that the quality of the effect depended on the quantity of the serum instilled. A dosage of 0.2 c.c. of horse serum generally produced fatal anaphylaxis, while a dose of 0.04 c.c. commonly conferred tolerance.

We could explain our results only on the hypothesis that the absorption of horse serum, according to cosage, initiated in the guinea-pig two opposite reactions, one of which was manifested by the anaphylactic state and the other by a condition of primary increased tolerance for the antigen. We further found that guinea-pigs prepared by a course of nasal instillations of serum, as compared with animals prepared by massive intraperitoneal injections, responded differently to a series of intravenous injections of horse serum. Animals given the preliminary treatments by the parenteral route, as is well known, tolerate continuously increased amounts of serum in spaced intravenous injections; but if a long resting period, say upward of 100 days, intervenes, there is more or less pronounced return toward hypersensitiveness.

When, on the contrary, guinea-pigs prepared by the nasal instillation of serum are submitted to a similar course of intravenous injections, tolerance for the antigen apparently increases with the length of the resting period, at least during the lapse of 125 days.

One of the fundamental data of immunology is the presence in the blood of an animal sensitized to a foreign serum of an anaphylactic antibody. When the serum of an animal sensitized to horse serum is injected into the peritoneal cavity of a normal guineapig, this creature itself passively acquires hypersensitiveness to horse serum.

* Read before the Section on Practice of Medicine at the Sixty Seventh Annual Session of the American Medical Association, Detroit, Seventh Annu
June, 1916.

1. Sewall, Henry, and Powell, Cuthbert: On the Conditions and Characters of the Immunity Produced in Guinea-Pigs by Instillation of Horse Serum into the Nose, Jour. Exper. Med., 1916, xxiv, No. 1.
In the present work we undertook to solve the following apparently simple problem: Given two guineapigs, one of which is hypersensitive to horse serum and the other resistant to it, does the serum of the latter animal contain anything which may neutralize or modify the admitted anaphylactic effects induced by the serum of the hypersensitive animal? An affirmative result would suggest the hypothesis of an "immune body" functionally opposite in action to that concerned in anaphylactic reactions.

The meager results thus far obtained are presented now only because it has become necessary to postpone indefinitely continuation of the work. This survey has employed seventy-two animals in twelve series of experiments. The crucial purpose of each group of experiments was to obtain the blood serum. of two guinea-pigs, one of which was highly resistant and the other highly sensitive to the intravenous injection of horse serum. The donor pigs were bled directly into tulses in which the serum was separated by centrifugation within half an hour. The serums from the two animals were injected at once, separately and mixed in various proportions, into the peritoneal cavities of normal guinea-pigs having an average weight of $300 \mathrm{gm}$. The mixed serums were incubated together for from fifteen to forty minutes, either at room temperature or at 37 C. $(98.6 \mathrm{~F}$.) before injection. After a resting period of from two to three days, these pigs received an intravenous injection of 0.25 c.c. of horse serum and, in case of survival, the injection was repeated at intervals of fourteen days or more.

Our usual method of procedure was to inject 3 c.c. of the serum from sensitive and resistant animals, respectively, into two normal guinea-pigs, and then mixtures of serums in the proportions $3+1,1+3$ and $1+1$ into other normal animals. Our first technical difficulty was encountered in the preparation of animals with such a high blood content of anaphylactic antibody that a normal pig receiving 3 c.c. of the serum would succumb in forty-eight hours to the intravenous injection of 0.25 c.c. of horse serum. In most cases the recipient pig was only shocked with the first intravenous injection, succumbing to the second. The usual preparatory treatment of pigs designed to develop anaphylactic antibodies consisted in from three to four daily intraperitoneal injections of from 2 to 5 c.c. of horse serum, the pigs being bled from fourteen to forty-eight days later.

It is obvious that the degree of sensitization acquired by the normal pigs, as a result of the intraperitoneal injection of sensitized serum, would be manifested as an anaphylactic response to the first intravenous injection of horse serum.

Eight of the forty-six normal animals receiving the serum of treated pigs died with the first intravenous injection of horse serum. Three showed no definite reaction, one of these succumbing to the second intravenous injection. The remainder showed a varying degree of reaction.

It is further obvious that the first intravenous injection of 0.25 c.c. of horse serum would, under ordinary conditions, strongly sensitize the guinea-pigs so that they would invariably succumb to a second injection of a like amount repeated after fourteen days or longer.

Our experiments show, however, that eleven of the forty-six pigs receiving serum of the treated animals withstood the second intravenous injection, and seven withstood three or more such injections, none of these, in fact, dying under treatment. The guinea-pigs used 
as donors of serum may be divided into two general classes. Those of the first class had been treated by the instillation of horse serum into the nose, but did not receive thereafter the usual intravenous injec-. tion of this serum. Half of these animals were instilled with what we call "protective" doses of 0.04 c.c. of horse serum, and half with "sensitizing" closes of 0.2 c.c. of the serum. From the results of parallel experiments it was assumed that the animals instilled with the smaller dosage would have withstood an intravenous injection of 0.25 c.c. of horse serum in sixteen days, and that those instilled with the larger dosage would have succumbed to such an injection. More ample experience has shown that this sharp biologic distinction between animals according to the amount of antigen which they have received cannot always be predicated; nevertheless it is obvious that remarkable and specific properties may be acquired by the serum of guinea-pigs treated only by instillation of horse serum, without subsequent reinforcement with intravenous injection. This is shown in Table 1.

The letter $\mathrm{L}$ in the table signifies that the guineapig survived its intravenous injection with scarcely perceptible reaction; the number of + signs indicates degrees in severity of anaphylactic shock.

It will be seen in the third column that every pig was to a degree sensitized by the intraperitoneal injection of serum from the donor animals. In the fourth column we see that pigs Nos. 5 and 6 , which had received mixtures of serum from donors $\mathrm{A}$ and $\mathrm{B}$ (the mixtures having stood at room temperature for about thirteen minutes) survived the second intravenous injection, and repetitions of the same at various intervals and with increasing dosage.

We defer speculation as to the meaning of these facts until the general discussion at the close of this

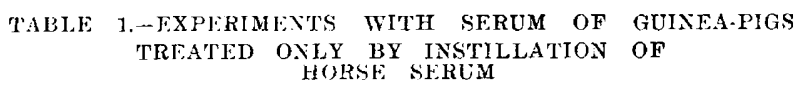
TREATED ONLY BY INSTILLATION OF HORSE SERUM

\begin{tabular}{c|c|c|c|c|c|c}
\hline \hline & & & \multicolumn{3}{|c|}{ Results of Intravenous Injection } \\
of Horse Serum*
\end{tabular}

* In this and the following tables, D means "dies"; L means "lives after very slight reaction": $\mathbf{L}++++$ means "very severe reaction."

+ Preparation of donor pigs: A, immune; received six nasal instiha tions of 0.04 c.c. horse serum, alternate days; $B$, sensitive; like treatment with 0.2 c.c. horse serum. Both bled after 21 days.

article. Suffice it now to postulate that the recipient Guinea-Pigs 5 and 6 have acquired an active immunity. One hundred and nineteen days elapsed between the intraperitoneal injection of immune serum and the last intravenous injection of horse serum. During this time six injections of horse serum were given and, in spite of the increase in the amount of antigen, the immunity of the pigs was progressively strengthened after the third treatment.

In numerous experiments which we have performed on pigs born of immune and sensitive mothers, never have we seen one survive the second intravenous injection of horse serum. It might be maintained, of course, that our Pigs 5 and 6 acquired their active immunity from the small residue of horse serum remaining free in the circulation of the donors $A$ and $B$, but, as will be seen shortly, such an explanation is scarcely tenable. Nevertheless, this interpretation of the results is perhaps supported by the data conveyed in Table 2.

In this experiment both donor pigs were highly immunized against horse serum. After six nasal instil-

\begin{tabular}{|c|c|c|c|c|c|c|}
\hline \multirow[t]{2}{*}{ 'TABLE } & \multirow{2}{*}{\multicolumn{2}{|c|}{ HIGHLY IMMUNIZEI }} & \multicolumn{2}{|c|}{ WITH SERUM } & \multicolumn{2}{|c|}{ GUINEA-PIGS } \\
\hline & & & $D$ AGAIN & ST HOR: & E SERU & \\
\hline \multirow[b]{2}{*}{$\begin{array}{l}\text { Donor } \\
\text { Pigs* }\end{array}$} & \multirow[b]{2}{*}{$\begin{array}{l}\text { Normal } \\
\text { Pigs }\end{array}$} & \multirow{2}{*}{$\begin{array}{l}\text { - } \\
\text { Serum } \\
\text { Intra- } \\
\text { perito- } \\
\text { neally, } \\
\text { C.c. }\end{array}$} & \multicolumn{4}{|c|}{$\begin{array}{c}\text { Results of Intravenous Injections } \\
\text { of } 0.25 \text { C.c. Horso Serum }\end{array}$} \\
\hline & & & $\begin{array}{l}\text { First, } \\
47 \text { Hours } \\
\text { After } \\
\text { Intra- } \\
\text { perito- } \\
\text { neal }\end{array}$ & $\begin{array}{c}\text { Second, } \\
19 \text { Days } \\
\text { After } \\
\text { First } \\
\text { Intra- } \\
\text { venous }\end{array}$ & $\begin{array}{l}\text { Third, } \\
16 \text { Days } \\
\text { After } \\
\text { Second } \\
\text { Intra- } \\
\text { venous }\end{array}$ & $\begin{array}{l}\text { Fourth, } \\
45 \text { Days } \\
\text { After } \\
\text { Third } \\
\text { Intra- } \\
\text { venous }\end{array}$ \\
\hline$\stackrel{A}{\mathrm{~A}}$ & 1 & $\begin{array}{l}3 \\
3\end{array}$ & $\begin{array}{l}\mathrm{L} \\
\mathrm{D}\end{array}$ & L & $\mathbf{L}+$ & $\mathrm{L}++$ \\
\hline$A \& B$ & 3 & $\begin{array}{l}\text { A. } 1 \\
\text { B. } 1\end{array}$ & $\mathrm{~L}$ & $\mathbf{I}++$ & $\mathbf{L}+++$ & $\mathrm{L}++$ \\
\hline
\end{tabular}

* Donor pigs treated by a course of nasal instillations and later by intravenous injections of horse serum. A was bled 19 days after last intravenous of 0.75 c.c. horse serum. B was bled 27 days after intravenous of 0.88 c.c. horse serum.

lations of 0.04 c.c. of horse serum, each withstood, with scarcely perceptible reaction, the intravenous injection of 0.38 c.c. of horse serum after sixteen days. Sixteen days later a similar injection was borne with moderate reaction. Sixty-seven days later A reacted moderately to an intravenous injection of horse serum increased to 0.75 c.c., and in sixty-nine days $B$ responded in the same way to an intravenous injection of 0.88 c.c. of horse serum. These pigs were bled at the same time, A nineteen days after receiving 0.75 c.c. of horse serum, and $\mathrm{B}$ seventeen days after receiving 0.88 c.c. of the serum. It is seen that the normal recipient of B's serum died with the first intravenous injęction, while the other two recipients were immunized. The mixed stums of $\mathrm{A}$ and $\mathrm{B}$ were incubated at $37 \mathrm{C}$. for twelve minutes.

It is worth while noting that the immunity conferred on normal guinea-pigs by this method usually develops more slowly and less perfectly than in animals immunized after a course of nasal instillations of horse serum. ${ }^{1}$

Our experiments substantiate the opinion that the effect of serum transferred by intraperitoneal injection to a normal animal depends not only on its composition but also on the quantity injected and, when mixtures of the serum are used, on the relative amounts of "immune" and "sensitive" serum employed.

Our experiments are far too limited in number to establish the quantitative relations of the variables in this supremely practical problem. Nevertheless, certion conclusions seem to be indicated, thus: mixtures of immune and sensitive serums appear to be more potent to confer immunity on the normal guinea-pig than immune serum alone, and those mixtures which contain the smaller proportion of immune serum are apparently most effective in this direction.

Mixtures of the serum of two hypersensitive donors, on the other hand, appear to be quantitatively more potent to induce the anaphylactic state in normal pigs than either serum alone. 
In Table 3 the results of three series of experiments are condensed. In the first, the immune Pig A, after a course of nasal instillations with horse serum, had received at long intervals five intravenous injections of horse serum, the last, amounting to 0.75 c.c., being given 116 days before the pig was bled. The animal was a female, and offspring born to it late in the treatment were completely refractory to subcutaneous injection of 0.1 c.c. of horse serum, while offspring of a sensitive mother succumbed to such an injection. Pig $B$ was bled twenty-five days after its course of intraperitoneal injections; its serum, no doubt, would have been richer in anaphylactic antibodies had a longer

TABLE 3.-RISULT'S OF THREE SFRTES OF EXPERIMENTS

\begin{tabular}{|c|c|c|c|c|c|c|c|}
\hline \multirow[b]{2}{*}{$\begin{array}{l}\text { Domor } \\
\text { l'igs }^{*}\end{array}$} & \multirow[b]{2}{*}{$\begin{array}{c}\text { Normal } \\
\text { l'mss }\end{array}$} & \multirow{2}{*}{$\begin{array}{l}\text { Mixut } \\
\text { Selume } \\
\text { lotya- } \\
\text { petito- } \\
\text { metily, } \\
\text { C.e. }\end{array}$} & \multicolumn{5}{|c|}{ 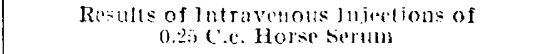 } \\
\hline & & & $\begin{array}{l}\text { First, } \\
6 . \text { Hours } \\
\text { After } \\
\text { Intra- } \\
\text { merito- } \\
\text { neal }\end{array}$ & $\begin{array}{l}\text { Second, } \\
14 \text { Days } \\
\text { After } \\
\text { First } \\
\text { lntra- } \\
\text { venous }\end{array}$ & $\begin{array}{l}\text { Third, } \\
13 \text { Days } \\
\text { After } \\
\text { Second } \\
\text { Intra- } \\
\text { venous }\end{array}$ & $\begin{array}{c}\text { Fourtl, } \\
\text { 14 Days } \\
\text { After } \\
\text { Third } \\
\text { lntra- } \\
\text { venous }\end{array}$ & $\begin{array}{c}\text { Filili, } \\
33 \text { Dilys } \\
\text { Aflir } \\
\text { Fontril } \\
\text { lutril } \\
\text { venouls }\end{array}$ \\
\hline \multirow[t]{2}{*}{$\begin{array}{l}A \& B \\
A \& B\end{array}$} & $\begin{array}{l}1 \\
2\end{array}$ & $\begin{array}{l}\text { A. } 2.5 \\
13,1.5 \\
A, 1.3 \\
13,2.5\end{array}$ & $\begin{array}{c}\mathrm{L}+ \\
\mathrm{L}++\end{array}$ & $\begin{array}{c}\mathrm{D} \\
\mathrm{x}+++\end{array}$ & $\mathrm{I}+++$ & $\mathbf{L}+$ & I. \\
\hline & & $\begin{array}{c}\text { Separate } \\
\text { and } \\
\text { Mixed } \\
\text { Serums }\end{array}$ & $\begin{array}{c}\text { First, } \\
37 \text { Hours } \\
\text { After } \\
\text { Intra- } \\
\text { perito- } \\
\text { neal }\end{array}$ & $\begin{array}{l}\text { Second, } \\
15 \text { Days } \\
\text { After } \\
\text { First } \\
\text { Intra- } \\
\text { venous }\end{array}$ & $\begin{array}{l}\text { 'l'luid, } \\
13 \text { Ditys } \\
\text { After } \\
\text { Second } \\
\text { Intra- } \\
\text { venous }\end{array}$ & $\begin{array}{c}\text { Fourth, } \\
36 \text { Ditys } \\
\text { After } \\
\text { Third } \\
\text { Intra- } \\
\text { Venous }\end{array}$ & \\
\hline \multirow[t]{2}{*}{$\begin{array}{c}C \\
C \& D \\
C \& D\end{array}$} & $\begin{array}{l}1 \\
2 \\
3 \\
4\end{array}$ & $\begin{array}{c}8 \\
3 \\
\text { C, } 3 \\
\text { D, 1 } \\
\text { C, J } \\
\text { D, } 3\end{array}$ & $\begin{array}{c}\text { L } \\
\text { L }+ \\
\mathrm{C}++\end{array}$ & $\begin{array}{c}\mathbf{L}+ \\
D \\
D\end{array}$ & $\mathrm{~L}+$ & $\mathbf{L}$ & \\
\hline & & $\begin{array}{l}\text { Separate } \\
\text { and } \\
\text { Mixed } \\
\text { Serums }\end{array}$ & $\begin{array}{c}\text { First, } \\
3 \text { Hours } \\
\text { After } \\
\text { Intra- } \\
\text { perito- } \\
\text { neal }\end{array}$ & $\begin{array}{l}\text { Second, } \\
\text { 14 Days } \\
\text { After } \\
\text { First } \\
\text { Intra- } \\
\text { venous }\end{array}$ & $\begin{array}{l}\text { 'Third, } \\
42 \text { Days } \\
\text { After } \\
\text { Second } \\
\text { Intra- } \\
\text { venous }\end{array}$ & & \\
\hline $\begin{array}{c}F \\
F \& F \\
\text { I. \& F }\end{array}$ & $\begin{array}{l}\frac{1}{2} \\
\frac{2}{3} \\
4\end{array}$ & $\begin{array}{c}5 \\
2 \\
E_{1}, 2 \\
\mathrm{~F}, 2 \\
\mathrm{E}, 1 \\
\mathrm{~F}, 2\end{array}$ & $\begin{array}{c}\mathrm{I}+ \\
\mathrm{L}++ \\
\mathrm{L}+ \\
\mathrm{I}+\end{array}$ & $\begin{array}{c}\mathbf{L}++ \\
\mathrm{D} \\
\mathbf{L}++ \\
\mathbf{L}++\end{array}$ & $\begin{array}{c}\mathrm{D} \\
\mathrm{L}++1\end{array}$ & & \\
\hline
\end{tabular}

* Preparation of donor pigs: A, immune pig: 6 nasal instillations, 0.2 c.c. horse serum followed by 5 intravenous injections in +5 months. last intravenous of 0.75 e.c. horse serum given 116 days before bleeding B, sensitized pig; 4 intraperitoneal injections of from 2 to 5 c.c. horse serum daily; bled 25 days after last intraperitoneal. $C$, immune pig: 4 nasal instillations of 0.2 c.c. horse serum followed by 3 intravenous injections of horse serum in 51 days, last intravenous of 0.5 c.e. horse serum given 103 days before bleeding. $D$, sensitized pig; prepared like $B$, bat bled 41 days after last intraperitoneal. $E$, immune pig; prepared

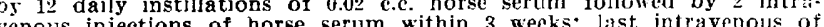
venous injections of horse serum within 3 weeks: last intravenous of c.ss c.c. horse serum lor days before bleeding. 17 days after last intraperitoneal.

interval elapsed. It is noticed that a stronger protection is afforded by the serum mixture containing the smaller amount of "immune" serum $A$. The same result is noted in Pig 4 of the third experiment. In the second experiment 3 c.c. of the serum of the sensitive Pig $D$ contained enough anaphylactic antibodies to make the normal Pig 2 fatally sensitive to an intravenous injection of horse serum. Although the serum of the immune Pig $\mathrm{C}$ was rich enough in protective substance to protect Pig 1 against a series of intravenous injections of horse serum, it could only partly inlibit the fatal effect of the serum of D when mixed with it.

After it had been determined that inmune serum and mixtures of immune and sensitized serum inoculated into normal guinea-pigs could protect them against anaplylactic death following intravenous injection of the antigen, it was obviousiy desirable to determine whether animals already hypersensitive to horse serum could be desensitized by similar treatment. A considerable number of experiments were performed in which guinea-pigs, sensitized to horse serum by subcutaneous injection, were given intraperitoneal injections of from 3 to 5 c.c. or more of serun and its mixtures, which probably would have protected normal animals against anaphylaxis. Each recipient pig was treated by an intravenous injection of horse serum in from three to seven days after the intraperitoneal injection, and each promptly died. We conclude that prophylaxis and cure of sensitization are practically independent problems. A useful discussion of the essential differences between prophylactic and therapeutic vaccination has been given by Theobald Smith."

\section{COMMENTS}

The present work must be considered in the light of facts announced in the previous article, ${ }^{1}$ of which it is a continuation.

We are strengthened in the opinion expressed a year ago ${ }^{3}$ that two different reaction bodies are formed in a normal animal when a foreign protein is introduced into its circulation. One of these is the anaphylactic antibody familiar to literature. The other is a protective antibody which averts the changes which result in anaphylactic shock. These antibodies probabiy always exist together in the circulation but, according to circumstances, in very different proportion. In the donor pigs which we have termed "sensitive" the anaphylactic antibody greatly predominates, while in the "immune" pigs the protective antibody is more or less pure. It is characteristic of the metabolism set up by the repeated absorption of very small quantities of horse serum by the nose that it results in the preponderant formation of the protective antibody. In an important research by Gurd, ${ }^{4}$ conclusions are expressed which agree, in parts, exactly with our own:

The experiments . . . are inferpreted by the author as proving the presence, in the circulating blood of immune aninals, of bodies which are potent to induce the liypersensitive state when introduced into normal animals and also of bodies which if injected in sufficient quantities are able to render normal animals immune.

We have shown that our "inmune" serum, that presumably surcharged with protective antibodies, is alone capable of protecting normal guinea-pigs against a series of inoculations of horse serum, and that mixtures of "immune" and anaphylactic serums appear to be still more potent in this direction.

Considerable evidence has been developed, both from laboratory and clinical fields, which supports the view that a disease-producing organism or substance when combined with certain contents of immune serum has a peculiarly vaccinating or even curative effect. ${ }^{5}$ Theobald Smith seven years ago suggested the employment of mixtures of toxin-antitoxin in the prophylaxis of diphtheria. The more recent use of "sensitized" vaccines is evidently founded on the same principle.

2. Sinith, Theobald: Boston Med. and Surg. Jour., 1910, clxiii, 275 . 3. Sewall, Henry and Powell, Cutlibert: Studies on the Relations of the Ilypersusceptibility and Insusceptibility Induced in Guinea-Pigs by the Instillation of Horse Serum into the Nose, Arch. Int. Med., October, 1915, p. 605.

4. Gurd F, B. Jour Med Research, 1914, xxxi, 205.

5. Wood, F, C., in lorchheimer's Therapensis of Internal Diseases, $1914, \mathrm{i}, 125$

6. Smith, Theobald: Jour. Exper. Med., 1909, xi, 241. 
A rich experience has been accumulated by students of hog cholera. ${ }^{7}$ Prophylaxis against this disease may be secured by the subcutaneous inoculation of rormal animals with "hyperimmune" serunt, that is, serum from immune hogs that have withstood inoculation with actively infected blood. This treatment is not curative of the disease, and its protective power disappears after a few weeks. Prophylaxis by the "simultaneous" method is much more effective. According to this plan, a considerable quantity of hyperimmune serum is injected under the skin on one side of the animal, and a small amount of virulent blood is injected on the other side. The protection conferred is said to last throughout life, and hogs actually sick with the disease are cured in a considerable proportion of cases. Duval and Couret ${ }^{8}$ have recently reported highly successful vaccination with "desiccated, sensitized hog cholera virus." They incubate the diseased tissues with hyperimmune serum, then dry and reduce them to a powder which is found effective for prophylaxis in exceedingly small amounts.

We venture to offer the following explanation of the facts presented: The protective antibodies of our immune pigs when injected into normal animals combine with cells and initiate in them the tendency to produce similar antibodies under appropriate stimulation. Such stimulation is found in the antigen contained in horse serum. The result of such injection is a response of the body cells by which they produce such excess of protective over anaphylactic antibodies that repeated injections of horse serum are withstood. 'The evidence is that the effect of the protective antibody in directing, the tisste metabolism is greatly enhanced by the presence in certain proportion of anaphylactic antibodies as found in the mixed serums. This is seen in Table 1. The rôle, then, of these reaction bodies injected into the normal animal is to modify cellular irritability in a manner to lead to the speedy and preponderant formation of "protective" antibodies under the stimulus of the antigen, and thus initiate the course of active immunity. The final status of the irritability of a living cell is determined, not only by the kind and amount of stimulating material invading it, but also by the metabolic predisposition of the cell at the moment of contact.

\section{SUMMARY AND CONCLUSION}

Our work was undertaken with the design of discovering whether the blood serum of guinea-pigs rendered immune to considerable intravenous injections of horse serum by a preceding course of nasal instillation of the serum has a different biologic effect from the serum of highly sensitive animals, when injected intraperitoneally into normal guinea-pigs. We have found that the serum of animals which we call immune can confer on normal guinea-pigs a resistance against a long succession of intravenous injections of the same antigen. It is also probable that mixtures of immune and sensitive serums in certain proportions give still greater protective effects. Notwithstanding the numerical inadequacy of these experiments, we believe that, taken in connection with the broader research, ${ }^{1}$ they justify the following tentative conclusion: A foreign protein injected into a normal animal sets up reactive processes leading to the formation, in this

7. Dorset, M.; McBryde, C. N., and Niles, W. B.: Bull. 102, Bur. An. Ind., U. S. Dept. Agric., 1908. Dorset, M.: Farmers' Bull. 379, U. S. Dept. Agric., 1909.

. D. Duval, C. W., and Couret, M. J.: Read before the Association of American Physicians, May 11, 1916. field, of two antiborlies having opposite characters; one tends to induce, and the other to avert, the establishment of the anaphylactic state.

Serum containing an excess of the anaphylactic antibody, when transferred to normal animals, renders them, as is well known, passively anaphylactic. Serum containing a sufficient excess of the "protective" antibody, when transferred to normal animals, initiates in them the phenomena of active immunity. Mixtures of the two types of serum seem still more effective in conferring immunity.

The metabolism of the body cells is specifically modified by combination with these antibodies in such a way as to give rise to hypersensitization on the one hand or to active immunity on the other.

If our interpretation of these results is correct, it is evident that new definitions must be given for "immune" serums.

\section{ABSTRACT OF DISCUSSION}

Dr. F. G. Novy, Ann Arbor, Mich.: Dr. Sewall in his results on the treatment of anaphylactic shock has described a protective action. It seems to me immunity begins with the shock itself. As to the nature of anaphylaxis: We have been accustomed to look on the chemical changes in the body as the most important feature. I am certain that it will be found that these changes are purely physical from beginning to end and that there is no chemistry connected with it.

Dr. S. J. Meltzer, New York City: Dr. Sewall is possibly the first one to test the effect of serum not by its action in anaphylactic shock but by its action when it did not kill and later when it protected. He discovered that when subminimal doses were used it was protective. But all such findings must be confirmed before they can be accepted as facts. It is very important to use the serum in small doses by his method. Nobody will object to the use of serum to protect them from infections or against possible anaphylactic shock. It has been found that guinea-pigs may be made either hypersensitive or insensitive to the action of horse serum following the placing of it in the nose and not in the stomach. It might be a good plan to give it by the stomach if the stomach is not full.

Dr. Henry Sewall, Denver: As to taking the serum by way of the mouth, in a few cases in which I have tried it the results have been negative. The mucous membrane of the mouth absorbs any foreign protein slowly. Again, if it is introduced into the stomach by means of a tube certain errors enter into it and one may lacerate the epithelium.

The Printing Press. - I am the printing press, born of mother earth. My heart is of steel, my limbs are of iron, and my fingers of brass. I sing the songs of the world, the oratorios of history, the symphonies of all time. I am the voice of today, the herald of tomorrow. I weave into the warp of the past the woof of the future. I tell alike the stories of peace and war. I make the human heart beat with passion or tenderness. I stir the pulse of nations, and make brave men do brave deeds, and soldiers die. I inspire the midnight toiler, weary at his loom, to lift his head again and gaze with fearlessness, into the vast beyond, seeking the consolation of a hope eternal. When I speak a myriad of people listen to my voice. The Anglo-Saxon, the Celt, the Hun, the Slav, the Hindu, all comprehend me. I am the tireless clarion of the news. I cry your joys and your sorrows every hour. I fill the dullard's mind with thoughts uplifting. I am light, knowledge, and power. I epitomize the conquests of mind over matter. I am the recorder of all things mankind has achieved. My offspring comes to you in the 'candle's glow, amid the dim lights of poverty, the splendor of riches; at sunrise, at high noon, and in the waning evening. I am the laughter and tears of the world, and I shall never die until all things return to the immutable dust. I am the printing press.-R. H. Davis. 